\title{
KONTRAK BUILD OPERATE TRANSFER (BOT)SEBAGAI PERJANJIAN KEBIJAKAN ANTARA PEMERINTAH DENGAN PIHAK SWASTA
}

\author{
Oleh : \\ Purbowicaksono \\ Email : purbowicaksono167@gmail.com \\ Universitas Narotama Surabaya
}

\begin{abstract}
Abstrak
BOT (Build Operate Transfer) sebagai bentuk perjanjian yang diadakan oleh kebijakan pemerintah dengan pihak swasta adalah perbuatan hukum oleh badan atau pejabat administrasi Negara yang membuat kebijakan publik sebagai obyek perjanjian. Meskipun yang melekat dalam dirinya sebagai pejabat badan atau publik, pemerintah dalam melaksanakan hubungan kontrak dengan pihak lain (swasta) perbuatan hukum yang tidak diatur oleh hukum publik, namun berdasarkan undang-undang dan peraturan hukum perdata (privaat recht), sebagai kasus undang-undang yang mendasari tindakan hukum perdata dilakukan tubuh warga dan hukum perdata. Penelitian menunjukkan bahwa dalam hubungan kontrak, pemerintah sebagai pihak dalam kontrak BOT tidak memiliki kedudukan yang sama dengan rekan-rekan mereka. Ini akan dibahas secara lebih mendalam dalam studi hukum dengan pendekatan yuridis normatif atau studi dalam kontrak BOT sebagai kebijakan kesepakatan.
\end{abstract}

Kata kunci : Kontrak BOT, perjanjian, kebijakan

\begin{abstract}
BOT (Build Operate Transfer) as a form of agreement held by the government policy with private parties is a legal act by the agency or the State administration officials who make public policy as the object of the agreement. Although inherent in him as a body or public official, the government in implementing the contractual relationship with another party (private) legal act is not governed by public law, but based on the laws and regulations of civil law (privaat recht), as the case of legislation that underlie civil legal actions carried out a body of citizens and civil law. The research shows that in a contractual relationship, the government as a party to the BOT contracts have no equal footing with their counterparts. This will be discussed in more depth in the study of law with the approach of juridical normative or study in a BOT contract as an agreement policy.
\end{abstract}

Keywords: BOT contract, agreement, policy 


\section{PENDAHULUAN}

\subsection{Latar Belakang}

Pembangunan sarana dan prasarana sebagai penunjang tercapainya tujuan bernegara memang harus dilakukan. Namun tidak dapat juga dihindarkan kenyataan bahwa pemerintah mempunyai kemampuan terbatas sehingga dibutuhkan kerjasama dengan pihak swasta dalam mewujudkan semua kebutuhan tersebut. Maka perjanjian pemerintah sebagai penentu kebijakan negara dengan swasta sebagai pihak yang bekerja sama untuk mewujudkan lancarnya pembangunan sarana dan prasarana juga tidak dapat dihindarkan. Selanjutnya kontrak-kontrak kerjasama pemerintah, baik pusat maupun daerah, dengan swasta menjadi suatu hal yang biasa.

Sebuah perjanjian yang melibatkan pemerintah tidak sama dengan perjanjian yang hanya melibatkan pihak swasta atau perjanjian antara orang perorang. Pemerintah merupakan sebuah badan hukum publik yang harus mempertanggungjawabkan berbagai kebijakan yang diambilnya kepada masyarakat. Pemerintah juga melibatkan aset yang cukup besar, baik berupa keuangan ataupun aset negara yang lain (barang, tanah). Jadi walaupun kontrak yang dibuat oleh pemerintah dan swasta dalam hal pembangunan infrastruktur untuk menunjang roda perekonomian ini bersifat privat didalamnya juga mengandung kepentingan publik.

Tipe kontrak konstruksi BOT secara garis besar merupakan model kontrak yang melibatkan dua pihak yakni pengguna jasa, pada umumnya pemerintah, dan penyedia jasa yakni pihak swasta. Pengguna jasa memberikan kewenangan kepada penyedia jasa untuk membangun infrastruktur dan mengoperasikannya selama waktu tertentu (disebut juga masa konsesi) dan penyedia jasa akan menyerahkan kepada pengguna jasa infrastruktur tersebut bila masa konsesi telah habis. Pola Kontrak BOT ini akhirakhir banyak digunakan terutama untuk pembangunan infrastruktur yang menyangkut hajat hidup orang banyak.

Berbagai hal yang dilakukan oleh pemerintah termasuk dalam menentukan bentuk kontrak yang akan digunakan adalah bagian dari kebijakan. Terkadang kebijakan yang dipilih menimbulkan bentuk permasalahan tersendiri. Demikian juga kebijakan untuk menggandeng pihak swasta dalam melakukan perwujudan pembanguan infrastruktur. Perbuatan hukum yang dilakukan oleh pemerintah dan swasta dalam kerjasama pembangunan infrastruktur akan menimbulkan akibat hukum seperti adanya prestasi-prestasi yang harus dipenuhi oleh para pihak. Apabila pola BOT dipilih sebagai bentuk kerjasama maka dibutuhkan pengetahuan yang cukup bagi aparat 
(pemerintah) pusat atau daerah untuk melaksanakanya. Pelaksanaan yang salah akan membawa kerugian baik bagi pemerintah sendiri maupun bagi masyarakat termasuk juga investor.

\subsection{Perumusan Masalah}

Berdasarkan latarbelakang yang telah dipaparkan di atas, maka permasalahan yang akan diteliti dapat dirumuskan sebagai berikut:

1. Apakahdasar keabsahan mengenai perjanjian kontrak dengan sistem Build Operate Transfer (BOT) ?

2. Apa kedudukan hukum antara pemerintah dengan pihak swasta terhadap perjanjian kontrak BOT ?

\section{METODE PENELITIAN}

Tulisan ini menggunakan metode penelitian hukum normatif, yaitu meneliti hukum dari perspektif internal dengan objek penelitiannya adalah norma hukum. Dengan kata lain penelitian hukum yang meletakkan hukum sebagai sebuah bangunan sistem norma. Sistem norma yang dimaksud adalah mengenai asas-asas, norma, kaidah dari peraturan perundangan, putusan pengadilan, perjanjian serta doktrin (ajaran). ${ }^{1}$

Pendekatan yang digunakan adalah pendekatan perundang-undangan dan

\footnotetext{
1 I Made Pasek Diantha, 2016,Metodologi Penelitian Hukum Normatif dalam JustifikasiTeori Hukum (Jakarta : Prenada Media Grup), hlm.12
}

pendekatan konseptual. Pendekatan perundang-undangan atau statute approach digunakan jika permasalahan penelitiannya mempermasalahkan konflik norma yang terjadi secara vertikal maupun horizontal.

Dalam setiap penelitian atau survei terhadap sesuatu masalah dapatlah digunakan bermacam-macam cara atau metode seperti melakukan penelitian atau survei secara kepustakaan, melakukan interview dan sebagainya.

Pendekatan konseptual atau conceptual approach beranjak dari pandanganpandangan dan doktrin-doktrin yang berkembang di dalam ilmu hukum, sehingga dapat menemukan ide-ide yang melahirkan pengertian-pengertian hukum, konsep-konsep hukum, dan asas-asas hukum yang relevan dengan isu yang dihadapi. $^{2}$

\section{PEMBAHASAN}

\subsection{Keabsahan Mengenai Perjanjian Kontrak Dengan Sistim Build Operate Transfer (BOT)}

Substansi kontrak pemerintah dapat berupa kontrak pengadaan dan kontrak nonpengadaan.Perbedaan tersebut terletak pada tujuan pembuatan kontrak.Kontrak pengadaan jelas dimaksudkan untuk pengadaan barang dan jasa, sedangkan

${ }^{2}$ Ibid, hlm. 159 
kontrak non pengadaan bukan dalam rangka pengadaan, melainkan dalam banyak hal untuk pelayanan publik.Dalam perspektif Indonesia perbedaan itu meliputi juga perbedaan dari sisi anggaran.Dari sisi ini, kontrak pengadaan merupakan kontrak yang dapat menimbulkan beban pembayaran sedangkan kontrak nonpengadaan pada umumnya merupakan kontrak yang menghasilkan pemasukan dari segi keuangan.

Kontrak nonpengadaan oleh pemerintah meliputi berbagai macam jenis. Melalui prinsip kebebasan berkontrak pemerintah dapat mengikatkan diri ke dalam jenis kontrak apapun baik yang tergolong sebagai perjanjian bernama maupun perjanjian yang tidak bernama atau perjanjian campuran. ${ }^{3}$ Seperti halnya kontrak BOT walaupun secara normatif tidak ada undang-undang yang secara khusus mengatur tentang kontrak ini tetapi secara sporadis sebagai bentuk atau cara untuk melaksanakan perjanjian atau kontrak kerjasama yang diadakan oleh pemerintah dapat kita jumpai dalam beberapa aturan. Pertama, Keputusan Menteri Keuangan Republik Indonesia Nomor 248/KMK. 04/1995 tentang Perlakuan Pajak Penghasilan Terhadap Pihak-Pihak yang Melakukan Kerjasama dalam Bentuk BOT,

\footnotetext{
${ }^{3}$ Yulianti, Rahmani Timorita. "Asas-Asas Perjanjian (Akad) dalam Hukum Kontrak Syari'ah".La Riba Jurnal Ekonomi Islam, Vol. II, No. 1, Juli 2008.
}

kedua, Peraturan Pemerintah Nomor 8 tahun 1990 tentang Jalan Tol. Dalam Pasal 38 diatur bahwa pemerintah melalui Badan (PT.Jasa Marga) dapat bekerjasama dengan pihak lain dalam pembangunan dan pengoperasian jalan tol dengan pola kerjasama BOT; Ketiga, Pasal 45 ayat 3 Penjelasan dalam Undang-Undang Nomor 7 tentang Sumber Daya Air; Keempat, Peraturan Pemerintah No 6 Tahun 2006 tentang Pengelolaan Barang Milik Negara/ Daerah pasal 20 dikatakan: Bentuk-bentuk pemanpaatan barang milik negara atau daerah berupa sewa, pinjam pakai, kerjasama pemanfaatan, bangun guna serah (BOT) dan bangun serah gunaBOT.

Kontrak BOT saat ini sering dipraktekkan oleh pemerintah khususnya pada proyek-proyek infrastruktur berskala besar, proyek BOT pertama kali dibidang power plant di Indonesia adalah PT.Paiton Energy atau lebih dikenal dengan Paiton I. Proyek listrik bertenaga batu bara dengan kekuatan 2x615 MW itu melakukan Financial closing pada tangal 21 april 1995. Kontrak proyek ini menggunakan Build Own Operate (BOO) dengan satu ketentuan "take or pay" pada awalnya masa kontrak disepakati selama 30 tahun tetapi kemudian setelah negosiasi ulang menjadi 40 tahun

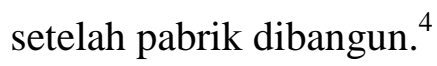

Ada beberapa keuntungan yang diperoleh dalam proyek pembangunan dengan pola BOT. Pertama, memperoleh 
sumber modal baru dari pihak swasta, agar dapat mengurangi pinjaman pemerintah dan pengeluaran langsung, yang kemungkinan dapat memperbaiki nilai hutang pemerintah. Kedua, mempercepat pembangunan proyek tanpa harus menunggu perolehan dana yang cukup besar. Ketiga, memakai keahlian pihak swasta untuk mengurangi biaya kontruksi, memperpendek jadwal dan efisiensi pengoperasian proyek. Keempat, alokasi resiko dan beban proyek pada pihak swasta; Lima, keterlibatan private sponsors dan comercial lender yang berpengalaman, yang menjamin kelayakan proyek. Keenam, pemerintah tidak perlu mengontrol proyek secara berlebihan, karena sudah diserahkan pada pihak swasta hinga akhir masa konsesi.Ketujuh, transfer teknologi dan pelatihan personil lokal.Kedelapan, sebagai tolak ukur efisiensi antara proyek swasta dengan proyek pemerintah yang sejenis. Kesembilan, keterlibatan Pemerintah Daerah dalam pola BOT akan berhasil ganda, selain langsung menggairahkan iklim investasi dan peningkatan eskalasi pembangunan setempat, juga sekaligus meningkatkan Pendapatan Asli Daerah (PAD) ditengah masyarakat yang well inform karena dipermudah mendapatkan akses global.

Pelaksanakan kontrak kerjasama dengan pola BOT, para pihak (pemerintah dan swasta) tentu harus mempersiapkan modal dan asset baik berupa uang, barang, dan jasa, yang akandijadikan sebagai nilai tawar (bargain) dengan prinsip saling mengutungkan, sehinga masing-masing pihak mau mengadakan perjanjian tersebut. Walaupun pemerintah dalam kontrak BOT mempersiapkan modal baik berupa barang atau jasa pada kontrak ini, namun pihak swasta dituntut untuk lebih berperan dalam menanggulangi berbagai kebutuhan yang diperlukan dalam proyek pembanggunan infrastruktur yang akan dibangun, baik pada tahap persiapan, pelaksanaan serta tahap operasionalnya. Walaupun pemerintah mempersiapkan modal dalam kontrak ini namun didalam BOT, pihak swasta dituntut lebih berperan untuk menyediakan modal untuk membangun berbagai fasilitas baru. Pemerintah akan menyetujui untuk mengeluarkan tingkat produksi yang minimum untuk memastikanbahwa operator pihak swasta bisa menutupi dalam biaya pengelolahan.

BOT atas barang milik daerah ini dilaksanakan oleh Pengelola Barang setelah mendapatkan persetujuan Gubernur, Bupati atau Walikota. Jadi tanah yang status pengunaannya ada pada Penguna Barang dan telah direncanakan untuk penyelengaraan tugas pokok dan fungsi pengguna barang yang bersangkutan, dapat dilakukan Bangun Guna Serah setelah tanah itu terlebih dahulu diserahkan pada Gubernur /Bupati /Wali kota. BOT dilaksanakan oleh pengelola barang dengan mengikut-sertakan 
Penguna Barang dan atau Kuasa Pengguna Barang. Kuasa Pengguna Barang adalah Kepala satuan kerja atau Pejabat yang ditunjuk oleh Pengguna Barang menggunakan barang yang berada dalam penguasaanya dengan sebaik-baiknya sesuai dengan tugas pokok dan fungsinya. Kemudian penetapan status pengunaan barang milik daerah sebagai hasil dari pelaksanaan BOT dilaksanakan oleh Gubernur/Bupati/Walikota dalam rangka penyelengaraan tugas pokok dan fungsi Satuan Kerja daerah terkait.Mitra kerjasama Pemerintah dalamkontrak BOT tersebut.

\subsection{Kedudukan Hukum Antara Pemerintah Dengan Pihak Swasta Terhadap Per- janjian Kontrak BOT}

Sebagaimana individu melakukan usaha guna memenuhi kebutuhan dan kepentingan pribadinya, pemerintah juga dituntut untuk memenuhi kebutuhan publik (publik interest) secara permanen dan konstan. Seperti halnya individu melakukan hubungan kontraktual dalam memenuhi kebutuhannya maka pemerintah pun melakukan hal yang sama. Pola kontraktualisasi ini digunakan oleh pemerintah sebagai salah satu cara dalam melaksanakan fungsinya di samping tindakan-tindakan sepihak (unilateral acts) yang didasarkan pada kewenangan dan perintah (authority of comand). Namun sebelum masuk tentang bagaimana posisi pemerintah dalam kontrak
BOT perlu halnya dipahami pengertian merintah sebagai salah satu pihak dalam kontrak (kontraktan). Sering kita mendengar bahwa istilah pemerintah dipersamakan dengan negara atau sebaliknya, padahal secara etimologis hal ini tidak benar, sekalipun memang fungsi negara nampak jelas dari apa yang dilakukan oleh pemerintah. Oleh karenanya dalam konteks kajian kontrak pemerintah pengertian pemerintah harus dipahami dalam arti organisasi pemerintah atau kumpulan dari kesatuan-kesatuan pemerintahan dan bukan dalam pengertian fungsi pemerintahan atau kegiatan memerintah.Dalam berbagai literatur khususnya tentang kontrak pemerintah istilah pe-merintah memang tidak lazim didefinisikan melainkan hanya penjelasan mengenai kewenangan, baik kewenangan pemerintahan pusat atau daerah.

Pengunaan instrumen hukum perdata oleh pemerintah, khususnya hukum kontrak, dalam pengelolaan urusan pemerintahan yang biasa disebut kontraktualisasi, terjadi percampuran elemen privat dan publik dalam hubungan kontraktual yang terbentuk. Kontrak yang dibuat oleh pemerintah karenanya mempunyai karakteristik yang berbeda dengan kontrak privat pada umumnya. Implikasi adanya percampuran elemen privat dan publik itu tidak saja mengenai keabsahan dalam pembentukan kontrak, tetapi juga pada aspek pelaksanaan serta penegakan hukumnya 
(enforcement of the contract $)^{4}$.

Adanya unsur hukum publik inilah yang menyebabkan aturan dan prinsip hukum dalam kontrak privat tidak sepenuhnya berlaku bagi kontrak yang dibuat pemerintah.Badan atau pejabat tata usaha negara juga acap kali mengadakan hubungan hukum perjanjian dengan pihak swasta atau badan hukum perdata berkenaan dengan pengerjaan pembangunan suatu proyek pemerintah. Hubungan hukum yang melandasi perikatan mereka adalah tetap atas dasar perjanjian yang lazim dikenal didalam Buku III BW.

Memang kedudukan pemerintah dalam suatu hubungan kontraktual cukup istimewa. Keadaan ini pada akhirnya membawa kompleksitas pada hubungan hukum yang terbentuk. Disamping adanya kemungkinan penyalahgunaan keadaan (misbruik vanomstandigheden) yang merugikan pihak privat, tidak tertutup kemungkinan timbulnya persoalan hukum yang cukup rumit. ${ }^{5}$ Disamping karena faktor tidak memadainya aturan yang tersedia juga karena faktor kurangnya pemahaman pejabat publik dalam memanfaatkan instrument hukum perdata tersebut

4 Wirjono Projodikoro, 1989, Asas-Asas Hukum Perjanjian, Balai, Bandung, hal. 49

5 Nanda Amalia, "Kontrak baku dan badan penyelesaian sengketa dalam kontrak bisnis internasional", Suloh: Jurnal Penelitian Dan Pengkajian Hukum,Fakultas Hukum Universitas Malikussaleh, Vol.03, No.01, Tahun 2005, hlm7677. serta tidak tertutup kemungkinan malafide.

Dari pihak pemerintah kemungkinan yang tidak menguntungkan yang patut diperhitungkan dalam kaitan dengan kontrak pemerintah itu diantaranya adalah sebagai berikut.Pertama, pengunaan lembaga-lembaga hukum perdata oleh pemerintah dalam penyelengaraan urusan pemerintah itu tidak selalu pasti dimungkinkan dalam hal untuk mencapai suatu tujuan pemerintah itu tersedia bentuk-bentuk menurut hukum publik; kedua, pengaturan pembagian wewenang intern jajaran pemerintah kadangkadang menjadi kacau dengan digunakanya suatu jalur hukum perdata; ketiga, efektifitas pengawasan preventif dan represif maupun jalur banding administratif ada kalanya tidak dapat ditempuh; keempat, dengan posisinya yang khusus karena berkewajiban menjaga dan memelihara kepentingan umum, pemerintah menuntut dalam hubungan hukum yang diciptakan suatu kedudukan yang khusus pula yang memberikan hak untuk melakukan pemu- tusan perjanjian secara sepihak; kelima, penggunaan lembaga hukum perdata dalam penyelengaraan urusan pemerintahan mudah sekali menjurus kearah bentuk de'tournement de procedure, artinya dengan menempuh jalur perdata tersebut lalu menyimpang dari jaminan-jaminan prosedural atau lain-lain jaminan perlindungan hukum yang dapat diberikan oleh hukum publik; keenam, pemerintah dapat 
menyalahkan posisi yuridisnya, karena denganjalurperdata itu kemungkinan-kemungkinan yang dapat dipilih menjadi lebih leluasa; ketujuh, pemerintah juga dapat menyalahgunakan kenyataan posisinya sebagai penguasa yang berkuasa maupun sebagai pemegang monopoli atau kombinasi keduanya; dan kedelapan, dengan membuat perjanjian yang juga berlaku untuk waktu yang akan datang berarti pejabat mengikat para penerusnya yang mungkin tidak sependapat dengan perjanjian tersebut yang lalu dapat berakibat dibatalkan secara sepihak perjanjian yang telah dibuat itu.

Jadi adanya pelaksanaan pelayanan publik atau kuatnya unsur publik dalam kontrak pemerintah inilah menjadi sebab dan alasan bahwa pemerintah dalam setiap mengadakan kontrak seperti dalam kontrak BOT dengan mitranya mempunyai kedudukan yang tidak sama. Kedudukan pemerintah sebagai kontraktan diatas berlaku pada kontrak pemerintah baik yang bernama atau tidak bernama. Kemudian pelaksanaan pelayanan fungsi publik selalu terkait dengan anggaran keuangan negara. Dalam kaitan inilah pemerintah terikat dengan konstitusi dan undang-undang. Prinsip dalam penggunaan keuangan negara disatu sisi dan prinsip dalam pelayanan publik.Dengan demikian menjadi landasan bagi pemerintah dalam menjalin hubungan hukum kontraktual. Norma hukum publik JURNAL RECHTENS, Vol. 9, No. 1, Juni 2020 yang berkaitan dengan prosedur, kewenangan, pembentukan dan pelaksanaan kontrak berikut penyelesaian sengketa bertitik tolak dari prinsip perlindungan bagi kepentingan publik dan keuangannegara.

Terdapat batasan-batasan yang wajib ditaati oleh pejabat dalam kaitanya dengan pengelolaan keuangan negara. Asas umum tentang pengelolaan keuangan negara, khususnya yang terkait langsung dengan kontrak pemerintah adalah yang tertuang dalam Pasal 3 ayat 3 yang menyatakan bahwa "Setiap pejabat dilarang melakukan tindakan yang berakibat pengeluaran atas beban APBN atau APBD jika angaran untuk membiayai pengeluaran tersebut tidak tersedia atau tidak cukup tersedia". Kemudian pada Pasal 3 ayat 7 menyatakan "Keterlambatan atas pembayaran tagihan yang berkaitan dengan pelaksanaan APBN/ APBD dapat mengakibatkan pengenaan denda dan atau bunga. Namun berbeda halnya dengan kontrak pemerintah yang mengunakan pola BOT, ketentuan dalam undang-undang tersebut menjadi tidak berlaku karena pada prinsipnya kontrak ini tidak membebani APBN atau APBD. Seperti disebutkan dalam Pasal 27 ayat 1 huruf $b$ Peraturan Pemerintah No 6 tahun 2006 yang menyebutkan Bangun Guna Serah dan Bangun Serah Guna Barang milik negara atau daerah dapat dilaksanakan dengan persyaratan: Tidak tersedia dana dalam Anggaran Pendapatan dan 
Belanja Negara atau Daerah untuk menyediakan bangunan dan fasilitas yang dimaksud.

Walaupun kontrak pemerintah bertujuan melindungi kepentingan umum, kontrak ini tetap saja bersifat komersial. Artinya para pihak baik pemerintah sebagai penguna jasa dan swasta sebagai penyedia jasa berorientasi pada manfaat dari dibuat atau dilaksanakanya kontrak.Bagi penyedia jasa selaku mitra, jelas yang menjadi tujuan adalah memperoleh keuntungan.Dalam persfektif Indonesia, kontrak pemerintah dengan pola BOT yang didalamnya melibatkan pemerintah sebagai kontraktan termasuk dalam kategori perbuatan hukum privat.Hubungan hukum yang terbentuk merupakan hubungan hukum dalam lapangan perdata. Sekalipun didalam jenis kontrak ini terdapat pemerintah sebagai kontraktan dan berlaku syarat-syarat khusus hukum publik dalam pembentukanya, tetapi watak hubungan hukumnya adalah murni perdata. Keabsahan kontrak yang dibentuk diukur juga melalui pasal 1320 BW sebagai aturan umum yang menentukan keabsahan bagi semua jenis kontrak. ${ }^{6}$ Demikian pula menyangkut yuridiksinya bukan dalam lingkup peradilan tata usaha negara, melainkan peradilan umum.Ini merupakan konsekwensi dari tindakan pemerintahan

\footnotetext{
${ }^{6}$ Abdul Halim Barkatullah, "Menjual Hak Memilih Pada Pemilihan Umum Dalam Perspektif Hukum Perjanjian", Jurnal Konstitusi, Vol. I, No. 1, November 2008, hlm 33.
}

yang dilakukan oleh badan atau pejabat tata usaha negara selaku pelaku hukum keperdataan (civil actor) yang melakukan perbuatan hukum keperdataan.

Tindakan yang dilakukan oleh pejabat tata usaha negara mewakili pemerintah dalamsuatu hubungan kontraktual merupakan tindakan keperdataan.Kontrak yang dibuat dan atau ditandatangani dengan demikan tunduk pada aturan yang berlaku bagi kontrak privat. ${ }^{7}$ Dalam hal kontrak itu didahului dengan atau dituangkan dalam suatu keputusan (kebijakan), maka keputusan yang dimaksud bukan merupakan keputusan tata usaha negara yang menjadi kompetensi Pengadilan Tata Usaha Negara. ${ }^{8}$

Hal-hal yang menyangkut pembentukan, pelaksanaan, perubahan, dan atau pemutusan perjanjian, sekalipun tertuang dalam bentuk keputusan harus dinilai sebagai perbuatan hukum keperdataan. Keputusan yang demikian inilah yang menurut teori melebur dipahami sebagai keputusan yang melebur kedalam tindakan keperdataan. Teori ini dapat dilihat dan dianut dalam Pasal 2 huruf a UU No 5/1986 yang menyatakan "Keputusan tata usaha negara yang merupakan perbuatan hukum

\footnotetext{
${ }^{7}$ Ridwan Khairandi, Itikad Baik Dalam Kebebasan Berkontrak, Jakarta, Pascasarjana FH-UI 2003. Hal. 81

${ }^{8}$ Indroharto.Usaha Untuk Memahami UndangUndang Tentang Peradilan Tata Usaha Negara.Jakarta: Pustaka Sinar Harapan, 2005. Hlm. 45
} 
perdata tidak termasuk dalam pengertian Keputusan Tata Usaha Negara.

Pengecualian ini tetap dipertahankan dalam Undang-Undang No 9 Tahun 2004 tentang Perubahan Atas UndangUndang No 5 Tahun 1986 tentang Peradilan Tata Usaha Negara. Jadi aturan dan prinsip hukum dalam hukum perikatan yang tertuang dalam Buku III BW dengan demikian berlaku bagi kontrak pemerintah di Indonesia, baik yang bernama ataupun tidak bernama.

\section{KESIMPULAN}

1. Melalui prinsip kebebasan berkontrak pemerintah dapat mengikatkan diri kedalam jenis kontrak apapun baik yang tergolong sebagai perjanjian bernama maupun perjanjian yang tidak bernama atau perjanjian campuran. Seperti halnya kontrak BOT walaupun secara normatif tidak ada undang-undang yang secara khusus mengatur tentang kontrak ini, tetapi secara sporadis sebagai bentuk atau cara untuk melaksanakan perjanjian atau kontrak kerjasama yang diadakan oleh pemerintah dapat dijumpai dalam beberapa peraturan antara lain Keputusan Menteri Keuangan Republik Indonesia Nomor 248/KMK.04/1995 tentang Perlakuan Pajak Penghasilan Terhadap Pihak-Pihak yang Melakukan Kerjasama dalam Bentuk BOT.
2. Penggunaan instrumen hukum perdata oleh pemerintah, khususnya hukum kontrak, dalam pengelolaan urusan pemerintahan yang biasa disebut kontraktualisasi, terjadi percampuran elemen privat dan publik dalam hubungan kontraktual yang terbentuk. Kontrak yang dibuat oleh pemerintah karenanya mempunyai karakteristik yang berbeda dengan kontrak privat pada umumnya. Implikasi adanya percampuran elemen privat dan publik itu tidak saja mengenai keabsahan dalam pembentukan kontrak, tetapi juga pada aspek pelaksanaan serta penegakan hukumnya (enforcement of the contract). Adanya unsur hukum publik inilah yang menyebabkan aturan dan prinsip hukum dalam kontrak privat tidak sepenuhnya berlaku bagi kontrak yang dibuat pemerintah. Badan atau pejabat tata usaha negara juga acapkali mengadakan hubungan hukum perjanjian dengan pihak swasta atau badan hukum perdata berkenaan dengan pengerjaan pembangunan suatu proyek pemerintah. 


\section{DAFTAR PUSTAKA}

Abdul Halim Barkatullah, 2008, "Menjual Hak Memilih Pada Pemilihan Umum

Dalam Perspektif Hukum Perjanjian"

Indroharto,2005,Usaha Untuk Memahami Undang-undang Tentang Peradilan Tata Usaha Negara. Jakarta: Pustaka Sinar Harapan

I Made Pasek Diantha, 2016, Metodologi Penelitian Hukum Normatif dalam JustifikasiTeori Hukum (Jakarta: Prenada Media Grup.

Nanda Amalia, 2005, "Kontrak Baku Dan Badan Penyelesaian Sengketa Dalam Kontrak Bisnis Internasional", Suloh: Jurnal Penelitian Dan Pengkajian Hukum, Fakultas Hukum Universitas Malikussaleh, Vol.03, No.01,
Ridwan Khairandi, Itikad Baik Dalam Kebebasan Berkontrak, Jakarta, Pascasarjana FH-UI 2003.

Wirjono Projodikoro, 1989, Asas-Asas Hukum Perjanjian, Balai, Bandung,

\section{Peraturan Perundang-Undangan}

Kitab Undang-Undang Hukum Perdata ;

Undang-Undang No 9 Tahun 2004 tentang Peradilan Tata Usaha Negara;

Peraturan Pemerintah No 6 Tahun 2006 tentang Pengelolaan Barang Milik Negara/Daerah ;

Keputusan Menteri Keuangan Republik Indonesia Nomor 248/KMK.04/1995 tentang Perlakuan Pajak Penghasilan Terhadap Pihak-Pihak yang Melakukan Kerjasama dalam Bentuk BOT. 


\section{BIODATA SINGKAT PENULIS}

Purbowicaksono menyelesaikan pendidikan Sarjana Hukum di Fakultas Hukum Universitas Yos Sudarso, Surabaya pada tahun 2004. Saat ini tengah menyelesaikan program Magister Ilmu Hukum di Fakultas Hukum Universitas Narotama, Surabaya. 